\section{Susceptibility of Five Salmonid Fishes to Renibacterium salmoninarum}

\author{
Masahiro Sakai, Shizuo Atsuta \\ and Masanori Kobayashi
}

School of Fisheries Science, Kitasato University Sanriku, Iwate 022-01, Japan

Bacterial kidney disease (BKD) is an infection of salmonid fish caused by a gram-positive diplobacillus classified as Renibacterium salmoninarum $^{1)}$. This disease affects only salmonid fish and the infection of non-salmonid fish has not been reported ${ }^{2)}$. In Japan, BKD was first reported from masu salmon, Oncorhynchus masou, chinook salmon, $O$. tshawytscha, sockeye salmon, $O$. nerka and pink salmon, $O$. gorbuscha $a^{3)}$ and was rapidly spread to many parts of Japan. However, the susceptibility to the disease among salmonid fishes cultured in Japan has not been compared yet. In this study, the susceptibility to $R$. salmoninarum was compared among rainbow trout, $O$. mykiss, chum salmon, O. keta, coho salmon, O. kisutch, masu salmon and Japanese chair, Salvelinus pluvius.

\section{Materials and Methods}

In this study, $R$. salmoninarum KU8503 isolated from coho salmon in Iwate Prefecture in 1985 was used. The bacterium was grown on $\mathrm{KDM}-\mathrm{C}^{4)}$ for 14 days at $15^{\circ} \mathrm{C}$. Rainbow trout weighing about $20 \mathrm{~g}$ were supplied from Iwate Experimental Fisheries Station, and coho solmon (about $6 \mathrm{~g}$ ), masu salmon (about $4.2 \mathrm{~g}$ ) and Japanese char (about $15 \mathrm{~g}$ ) were received from private fish farms. Chum salmon (about $5 \mathrm{~g}$ ) was supplied from a chum salmon hatchery in Iwate Prefecture. Ten fish from each fish species were confirmed by an indirect fluorescent antibody test (IFAT) ${ }^{5)}$ and an indirect dot blot assay (IDBA) ${ }^{8)}$ that $R$. salmoninarum antigen was not detected from these fishes.

Challenge was conducted by the method of Sakai et $a l .^{7)}$ Fish were injected intraperitoneally with $10^{8}$ or $10^{7}$ bacterial cells suspended in PBS. After injection, groups of 18-60 fish were maintained at $12^{\circ} \mathrm{C}$ and the mortalities were recorded daily for 50 days. All moribund fish were necropsied and kidney smears were stained by Gram. For control, each fish species injected with the same volume of physiological saline (PS) were maintained in the same conditions.

Fifty days after infection, the kidney smears from all surviving fish were prepared on non fluorescent slides, and IFAT was used to detect the $R$. salmoninarum antigen. The heat extract of kidney from all surviving fish was also prepared by the method of Kimura and Yoshi$\mathrm{mizu}^{8)}$, and the presence of $R$. salmoninarum antigen was examined by IDBA.

\section{Results and Discussion}

Coho salmon inoculated with $2.0 \times 10^{8}$ cells/fish of $R$. salmoninarum began to die 11 days after inoculation with the number of deaths peaking 16-18 days after challenge. Mortality continued until 35 days after challenge and 21 of the 24 fish died $(87.5 \%)$. In the case of coho salmon inoculated with $2.0 \times 10^{7}$ bacterial cells, the accumulated mortality was $72.0 \%$. Grampositive $R$. salmoninarum like cells were observed from all dead coho salmon and following 4 salmonids. Chum salmon injected with $5.7 \times$ $10^{8}$ cells began to die 7 days after infection and all fish died within 18 days after challenge. For fish injected with $5.7 \times 10^{7}$ cells, the accumulated mortality was $98.1 \% 35$ days after challenge. The mortality of masu salmon was $91.0 \%$ in the fish group injected with $1.2 \times 10^{8}$ R. salmoninarum cells, and $53.0 \%$ for $1.2 \times 10^{7}$ cells. In the group of rainbow trout injected with $4.8 \times 10^{8}$ cells, the fish began to die 18 days after challenge with the number of mortalities peaking 27-30 days after challenge. In this group, $94.4 \%$ of the fish died. In the group injected with $4.8 \times 10^{7}$ cells, mortality was only $15 \%$. In the case of Japanese char, the mortality was $80.0 \%$ in the group injected with $1.2 \times 10^{8}$ cells and $16 \%$ in $1.2 \times 10^{7}$ cells.

The IFAT detected $R$. salmoninarum antigen from kidney smears of all surviving fish (Table 1). The same results were indicated by the IDBA.

Sanders et $\left.a l .{ }^{9}\right)$, who compared the susceptibility of sockeye salmon, coho salmon and steelhead trout to $R$. salmoninarum, concluded 
Table 1. Susceptivility of coho salmon, chum salmon, masu salmon, rainbow trout and Japanese char against Renibacterium salmoninarum

\begin{tabular}{|c|c|c|c|c|c|c|}
\hline \multirow{2}{*}{ Fish species } & \multirow{2}{*}{$\begin{array}{l}\text { Challenge } \\
\text { dose } \\
\text { (cells/fish) }\end{array}$} & \multirow{2}{*}{$\begin{array}{l}\text { Number of } \\
\text { fish } \\
\text { (N) }\end{array}$} & \multirow{2}{*}{$\begin{array}{l}\text { Number of } \\
\text { dead fish } \\
\text { (Mortality \%) }\end{array}$} & \multicolumn{3}{|c|}{$\begin{array}{l}\text { Number of surviving fish with } \\
R \text {. salmoninarum antigen }\end{array}$} \\
\hline & & & & Gram stain & IFAT $^{1)}$ & IDBA $^{2)}$ \\
\hline \multirow[t]{2}{*}{ Coho salmon } & $2.0 \times 10^{8}$ & 24 & $21(87.5)$ & 0 & 3 & 3 \\
\hline & $2.0 \times 10^{7}$ & 25 & $18(72.0)$ & 0 & 7 & 7 \\
\hline \multirow[t]{2}{*}{ Chum salmon } & $5.7 \times 10^{8}$ & 40 & $40(100)$ & 0 & 0 & 0 \\
\hline & $5.7 \times 10^{7}$ & 40 & $39(98.1)$ & 0 & 1 & 1 \\
\hline \multirow[t]{2}{*}{ Masu salmon } & $1.2 \times 10^{8}$ & 65 & $59(91)$ & 0 & 6 & 6 \\
\hline & $1.2 \times 10^{7}$ & 60 & $32(53)$ & 0 & 18 & 18 \\
\hline \multirow[t]{2}{*}{ Rainbow trout } & $4.8 \times 10^{8}$ & 18 & $17(94.4)$ & 0 & 1 & 1 \\
\hline & $4.8 \times 10^{7}$ & 20 & $3(15)$ & 0 & 17 & 17 \\
\hline \multirow[t]{2}{*}{ Japanese char } & $1.2 \times 10^{8}$ & 25 & $20(80)$ & 0 & 5 & 5 \\
\hline & $1.2 \times 10^{7}$ & 25 & $4(16)$ & 0 & 21 & 21 \\
\hline
\end{tabular}

IFAT $^{1)}$ : Indirect Fluorescent Antibody Test.

IDBA $^{2)}$ : Indirect Dot Blot Assay.

that sockeye salmon was the most sensitive to $R$. salmoninarum and steelhead trout was less sensitive. Kawamura et al. ${ }^{10)}$ observed that chum salmon was the most sensitive to this disease in experimental transmission from diseased masu salmon to chinook salmon, masu salmon, chum salmon and steelhead trout. Kaattari et al. ${ }^{11)}$ compared the sensitivities of chinook salmon, coho salmon and rainbow trout to $R$. salmoninarum and discussed the relationship between susceptibility and serum antibody titers against $R$. salmoninarum. Rainbow trout immunized with heat-killed and soluble $R$. salmoninarum antigen emulsified in Freund's complete adjuvant produced a much greater antibody response, followed by coho salmon and chinook salmon.

In this study, chum salmon was most susceptible to $R$. salmoninarum, and rainbow trout and Japanese char were less susceptible. However, there remains a possibility that the difference in susceptibility may be caused by the size of the fish, for rainbow trout and Japanese char used in this experiment were larger than the other fishes.

\section{References}

1) Fryer, J. L. and J. E. Sanders (1981): Ann. Rev. Microbiol., 35, 273-298. 2) Austin, B. and D. A. Austin (1987): In "Bacterial fish pathogens". John Wiley and Sons, Chichester, England, pp. 7087. 3) Kimura, T. and T. Awakura (1977): Bull Japan. Soc. Sci. Fish., 43, 143-150. (In Japanese with English summary.) 4) Daly, J.G. and R. M.W. Stevenson (1985): Appl. Environ. Microbiol., 50, 868-871. 5) Bullock, G. L. and H. M. Stuckey (1975): J. Fish. Res. Bd. Can., 32, 2224-2227. 6) Sakai, M., S. Atsuta and M. Kobayashi (1989): J. Aquatic Animal Health, 1, 21-24. 7) Sakai, M., S. Atsuta and M. Kobayashi (1989): Physiol. Ecol. Japan. Spec., 1, 577-586. 8) Kimura, T. and M. Yoshimizu (1981): Dev. Biol. Stand., 49, 219-224. 9) Sanders, J. E., K. S. Pilcher and J. L. Fryer (1978): J. Fish. Res. Bd. Can., 35, 8-11. 10) Kawamura, H., T. Awakura, K. Watanabe and H. Matsumoto (1977): Sci. Rep. Hokkaido Fish Hatchery, 32, 21-36. (In Japanese with English summary.) 11) Kaattari, S., D. Chen, P. Turaga and G. Wiens (1988): Bonneville Power Administration, Project 84-46, pp. 1-61, Annual Report 1987, Portland, Oregon. 